\title{
Studies and Regulation of the Disaster Management in Malang Indonesia
}

\author{
$1^{\text {st }}$ Prasetyo Isbandono \\ Public Administration Department \\ Universitas Negeri Surabaya \\ Surabaya, Indonesia \\ prasetyoisbandono@unesa.ac.id
}

\author{
$2^{\text {nd }}$ Noviyanti \\ Public Administration Department \\ Universitas Negeri Surabaya \\ Surabaya, Indonesia \\ noviyanti@unesa.ac.id
}

\begin{abstract}
Disaster management in general has undergone a change of paradigm is very fundamentally. Now the disaster mitigation is a series of efforts to reduce the risk of disasters, through physical development and awareness and capacity in disaster preparedness the scale of the index population exposed also can be divided into the category of low, medium and high, with the terms of the value of its index. the threat level every disaster potential in Malang is : Low, Middle, and High.

Policy priorities and Programs in Disaster Mitigation Malang Regency are strength rules and institutional capacity, integrated disaster mitigation planning, research, education and training, capacity building and community participation, the protection of community from disaster and disaster management.
\end{abstract}

Keywords-disaster management, mitigation, institutional capacity

\section{INTRODUCTION}

Geographically, Indonesia is the islands located on the meeting four plates of the tectonic plates of the Asian continent, shelf Australia, plates of the Indian Ocean and Pacific Ocean fins. On the southern and eastern Indonesia there are volcanic belt architectures extending from the Island of Nusa Dua Tenggara-Sulawesi Sumatera-Jawa, which sides in the form of old volcanic mountains and lowlands that some is dominated by swamps. The condition is very potential as well as disaster prone like volcanic eruption, tsunami earthquake, flood and landslide.

East Java Province is a disaster prone areas. The head of the National Agency for Disaster Management, Ma'arif stated that "East Java Province is a disaster supermarket area [1].

Disaster Relief efforts is a series of activities :(1) since before the disaster, which is called as prevention activities, disaster mitigation in disaster preparedness,; (2) the activities done at the time of a disaster called as emergency response activities and (3) activities after a disaster in the form of recovery activities or the rehabilitation and reconstruction. For that disaster mitigation actions need to be comprehensive and coordinated across the program and cross sector; and already charcoal of course which includes 3 stages/kinds mentioned activities.

Disaster management in general has undergone a change of paradigm is very fundamentally, namely from the disaster management (which his nature responsive-curative) turned into disaster risk reduction (which is the repress preventive); it means this time organizing disaster response focus more on the pre disaster from the emergency phase [2].

Law Number 24 Year 2007 about Disaster Response (Undang-Undang RI No. 24 Tahun 2007 tentang Tanggap Bencana) defines the disaster as events or a series of events that threaten and interfere with the lives and livelihoods caused by both natural factors and/or non-factor natural and human factors that lead to the sacrifice of the human soul, environmental destruction, property loss and psychological impact [3] [4]

Now the disaster mitigation is a series of efforts to reduce the risk of disasters, through physical development and awareness and capacity in disaster preparedness (Article 1 paragraph 9), refers to the rules above have formed formal institutional bodies at the center of the National Agency for Disaster Management (BNPB) as a replacement of BAKORNAS PB through President Regulation Number 8 Year 2008. BNPB consists of the elements of the steering committee and the elements of implementing disaster management [5].

At local government level, institutional reform $\mathrm{PB}$ is based on the Regulation of the minister in the land the Number 46 Year 2008 and Regulation of The Head of BNPB Regulation Number 3 Year 2008 [6][7][8].

\section{RESEARCH METHODS}

Malang District population in 2013 reached 2.619.069 soul, which consists of a number of men 1.306 .930 soul and the inhabitants of women some 1.312.139 soul, with the ratio of the sexes 99,01. In detail the following table presents the number of population in Malang Regency according to gender and the ratio of the sexes per sub district 2013 [9]. 
TABLE 1. The number of the inhabitants of the Malang Regency (According to Gender and the ratio of the sexes Per Sub District 2013)

\begin{tabular}{|c|c|c|c|c|c|}
\hline No & Sub-districts & Male & Women & $\begin{array}{c}\text { The } \\
\text { number } \\
\text { of }\end{array}$ & $\begin{array}{c}\text { The } \\
\text { ratio } \\
\text { of the } \\
\text { Sexes }\end{array}$ \\
\hline 1 & Donomulyo & 35.965 & 36.703 & 72.668 & 9797,99 \\
\hline 2 & Kalipare & 33.985 & 33.609 & 67.594 & 101,12 \\
\hline 3 & Pagak & 25.897 & 27.573 & 53.470 & 93,92 \\
\hline 4 & Bantur & 38.071 & 38.380 & 76.451 & 99,19 \\
\hline 5 & Gedangan & 29.583 & 29.159 & 58.742 & 101,45 \\
\hline 6 & $\begin{array}{l}\text { Sumber- } \\
\text { manjing }\end{array}$ & 50.558 & 48.913 & 99.471 & 103,36 \\
\hline 7 & Dampit & 66.984 & 68.051 & 135.035 & 98,43 \\
\hline 8 & Tirtoyudo & 31.991 & 32.459 & 64.450 & 98,56 \\
\hline 9 & Ampelgading & 29.620 & 29.704 & 59.324 & 99,72 \\
\hline 10 & $\begin{array}{c}\text { Poncokusum } \\
0\end{array}$ & 49.285 & 48.803 & 98.088 & 100,99 \\
\hline 11 & Wajak & 43.482 & 43.956 & 87.438 & 98,92 \\
\hline 12 & Turen & 61.431 & 62.448 & 123.879 & 98,37 \\
\hline 13 & Bululawang & 34.793 & 35.435 & 70.228 & 98,19 \\
\hline 14 & Gondanglegi & 44.255 & 44.371 & 88.626 & 99,74 \\
\hline 15 & Pagelaran & 35.251 & 36.716 & 71.967 & 96,01 \\
\hline 16 & Kepanjen & 50.366 & 50.902 & 101.268 & 98,95 \\
\hline 17 & $\begin{array}{l}\text { Sumber- } \\
\text { pucung }\end{array}$ & 29.295 & 30.388 & 59.683 & 96,40 \\
\hline 18 & Kromengan & 20.109 & 20.319 & 40.428 & 98,97 \\
\hline 19 & Ngajum & 25.820 & 25.837 & 51.657 & 99,93 \\
\hline 20 & Wonosari & 25.498 & 24.724 & 50.222 & 103,13 \\
\hline 21 & Wagir & 41.921 & 40.302 & 82.223 & 104,02 \\
\hline 22 & Pakisaji & 43.012 & 41.952 & 84.964 & 102,53 \\
\hline 23 & Tajinan & 26.050 & 26.535 & 52.585 & 98,17 \\
\hline 24 & Tumpang & 38.873 & 38.963 & 77.836 & 99,77 \\
\hline 25 & Pakis & 71.394 & 71.790 & 143.184 & 99,45 \\
\hline 26 & Jabung & 36.289 & 35.620 & 71.909 & 101,88 \\
\hline 27 & Lawang & 49.833 & 53.146 & 102.979 & 93,77 \\
\hline 28 & Singosari & 87.271 & 87.453 & 174.724 & 99,79 \\
\hline 29 & $\begin{array}{l}\text { Karang- } \\
\text { ploso }\end{array}$ & 37.210 & 36.763 & 73.973 & 101,22 \\
\hline 30 & Dau & 32.037 & 31.628 & 63.665 & 101,29 \\
\hline 31 & Pujon & 35.367 & 34.026 & 69.393 & 103,94 \\
\hline 32 & Ngantang & 29.809 & 29.429 & 59.238 & 101,29 \\
\hline 33 & Kasembon & 15.625 & 16.082 & 31.707 & 97,16 \\
\hline \multicolumn{2}{|c|}{ The number of } & $\begin{array}{c}1.306 . \\
930\end{array}$ & $\begin{array}{c}1.312 .13 \\
9\end{array}$ & $\begin{array}{c}2.619 .06 \\
9\end{array}$ & 99,60 \\
\hline
\end{tabular}

Source: BPS Malang District (from the results of the registration of the inhabitants of)

Based on Eurostat data on the number of the inhabitants of the most votes in District of Singosari reaching 174.724 soul that consists of 82.271 people male and female population soul 87.271. This is because the Singosari Subdistrict is industrial area which developed and relatively close to the region of Malang. While the total population at least in District Kasembon namely 31.707 soul that consists of 15.625 people male and female population soul 16.082 . This is because of the Sub-district Kasembon is one of the suburbs that directly borders with Kediri district and mountainous topography [9].

Disasters that have occurred in Malang Regency consist of natural and non-natural disasters and human-caused social disasters. There are 10 potential disasters identified based on historical events which can be seen in the following.
TABLE II. 10 Potential Disasters Identified Based on Historical Events

\begin{tabular}{|r|c|c|l|}
\hline \hline \multicolumn{4}{|c|}{ Potensi Bencana Kabupaten Malang } \\
\hline \hline 1 & Floods & 6 & Droughts \\
\hline 2 & Extremewaves and abrasions & 7 & Epidemics and disease outbreak \\
\hline 3 & Earthquake & 8 & Volcanic eruptions \\
\hline 4 & Forest and land fire & 9 & Extreme Weather \\
\hline 5 & Technological failures & 10 & Landslide \\
\hline \hline
\end{tabular}

Source: BPS Malang District

From the table can be explained more clearly some groups of disasters that have occurred in Malang Regency are floods, extreme waves and abrasions, earthquakes, forest and land fires, technological failures, droughts, epidemics and disease outbreaks, volcanic eruptions, extreme weather and landslide.

TABLE III. History of Disaster Events in Malang Regency

\begin{tabular}{|c|c|c|c|c|c|c|c|c|}
\hline KEJADIAN & 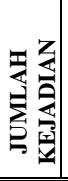 & 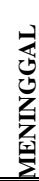 & 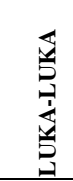 & 岁 & 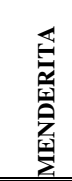 & 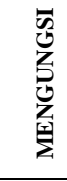 & 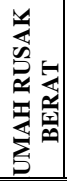 & 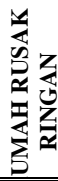 \\
\hline Banjir & 20 & 8 & 4 & 1.494 & 1.172 & 1.831 & 1 & 8 \\
\hline $\begin{array}{l}\text { Gelombang } \\
\text { Ekstrim Dan } \\
\text { Abrasi }\end{array}$ & 1 & - & - & - & - & 11 & - & - \\
\hline Gempa Bumi & 3 & - & 8.770 & - & 1.488 & - & - & - \\
\hline $\begin{array}{l}\text { Kebakaran } \\
\text { Hutan Dan } \\
\text { Lahan } \\
\end{array}$ & 1 & - & - & - & - & - & - & - \\
\hline $\begin{array}{l}\text { Kegagalan } \\
\text { Teknologi }\end{array}$ & 1 & - & - & - & - & - & - & - \\
\hline Kekeringan & 2 & - & - & - & - & - & - & - \\
\hline $\begin{array}{l}\text { Epidemi Dan } \\
\text { Wabah } \\
\text { Penyakit }\end{array}$ & 2 & - & - & - & - & - & - & - \\
\hline $\begin{array}{l}\text { Letusan } \\
\text { Gunung Api }\end{array}$ & 1 & - & - & - & - & - & - & - \\
\hline Cuaca Ektrim & 20 & - & 582 & 97 & 122 & 310 & 1 & 2 \\
\hline $\begin{array}{l}\text { Tanah } \\
\text { Longsor }\end{array}$ & 7 & - & - & 60 & 4 & 27 & - & - \\
\hline JUMLAH & 58 & 8 & 9.356 & 1.651 & 2.786 & 2.179 & 2 & 10 \\
\hline
\end{tabular}

Source: BPS Malang District

Data on the occurrence of disasters in Malang Regency in the period between 1815-2011 can be seen in the Indonesian Disaster Data and Information as seen in the table above.

\section{RESULT AND DISCUSSION}

In determining the level of the threat of disaster, can be done by using the matrix of the threat level that is combined with the threat of index on allocated with the index population is exposed on the column. The threat level is the meeting point between the index threats with the index population is exposed. The determination of the scale of the threat index can be divided into 3 categories namely: low index $(0.0-0.3)$, the index is $(>0.3-0.6)$ and high index (> 
0.6 - 1.0). While for the scale of the index population exposed also can be divided into the category of low, medium and high, with the terms of the value of its index is:

a. Low Index : When the density of the population is exposed to less than 500 people $/ \mathrm{km}^{2}$ and the number of the inhabitants of vulnerable groups less than $20 \%$.

b. The index is : When the density of the population is exposed to $500-1000$ people $/ \mathrm{km}^{2}$ and the number of the inhabitants of vulnerable groups $20 \%$ of $40 \%$.

c. High Index : When the density of the population is exposed to more than 1000 people $/ \mathrm{km}^{2}$ and the number of the inhabitants of vulnerable groups more than $40 \%$.

To view the level of threat in Malang district based on the type of disaster that the potential on the scale of the threat of each type of disaster and the scale of the population is exposed, can be seen in the picture below.

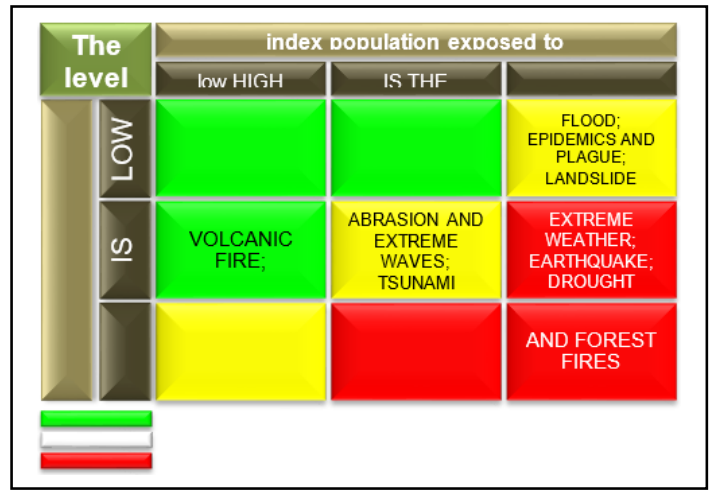

FIGURE 1. The matrix of the determination of the level of the threat of the disaster in Malang

From the picture above can explain that the threat level every disaster potential in Malang is:

- The level of the threat of catastrophic volcanic fire is low. This is because the index the threat is being index and the inhabitants of peoples' exposure low.

- Disaster threat level extreme waves and abrasion and tsunami is being. This is because the threat index is index and the inhabitants of peoples' exposure is also being. While the flood disaster, phase and outbreaks of disease and landslides have low threat index and the index population exposed to high.

- The level of the threat of extreme weather disasters, earthquakes and drought is high. This is because the index the threat is being index and the inhabitants of peoples' exposure high. While the catastrophic forest fires and land have high threat index and the population exposed to high also.

The determination of the index the threat of disasters in Malang Regency can be arranged based on the data and note the history of the disaster that never happened in Malang. The index the threat of the disaster was drafted based on the components of the possibility of a threat and the components of the massive impact that never recorded to the disaster. The threat index can be adjusted with the standard parameters that has been determined by BNPB with reference to map the threat of every disaster in Malang.

Policy priorities and Programs in Disaster Mitigation Malang Regency

\section{1). Strengthen Rules and institutional capacity}

Arrange the monitoring mechanisms and evaluate the implementation of the operation of the disaster response and Malang Regency have evaluation study guide the implementation of disaster response operations based on the record of communication and interviewing the related figures and there is a study of the evaluation of the implementation of the operation of the emergency response to disasters.

\section{2). Integrated Disaster Mitigation Planning}

- Strengthen the system information and the publication of disaster areas

- Optimize the results of Disaster Risk studies to draw up the policy and regional planning in cross-border relations administration area

\section{3). Research, Education and Training}

The identification and collection of the research result of regional disaster research that has been done to build the library research disaster areas so that the existence of the data base and the catalog of research on disaster areas and the existence of library research results disaster areas that can be accessed by wide.

\section{4). Capacity Building and Community Participation}

- Build local media access to the publication of disaster relief efforts in a transparent area

- Optimize the partnership in disaster response

\section{5). The Protection of The Community from Disaster}

- The prevention and Disaster Mitigation

- Disaster Preparedness

\section{6). The Disaster Management}

The disaster management is a policy that need to be taken at the time of crisis, the emergency period, and at the time of the restoration. The disaster management implemented to reduce the sacrifice at this time and speed up the process of normalization. To ensure the achievement of this policy, then the program focused on disaster relief and rehabilitation and reconstruction.

\section{CONCLUSION}

1). Some groups of Genesis disaster that never happened in Malang District is the flood, abrasion and extreme waves, earthquake, forest fires and land, the failure of the technology, drought, and epidemic of disease, volcanic fire, extreme weather and landslides.

2). The level of the threat of catastrophic volcanic fire is low. Disaster threat level extreme waves and abrasion and 
tsunami is being. The level of the threat of extreme weather disasters, earthquakes and drought is high.

3). Community Participation and capacity building with local media access to the publication of disaster relief efforts in a transparent area and optimize the partnership in disaster response.

4). The protection of the community from the disaster is done with prevention and Disaster Mitigation and disaster preparedness.

\section{ACKNOWLEDGMENT}

The authors would like to thank The Dean of Faculty of Social Science and Law - Universitas Negeri Surabaya facilities for giving some results of the study conducted.

\section{REFERENCES}

[1] S. Ma'arif, "Materials to increase the capacity of the apparatus of the body of the Disaster Area( BPBD) East Java Province.” BD of East Java Province, Surabaya, 2012.

[2] E. Hayati, Matter Socialization local regulations Nmor 3 Years 2010 about disaster response in the province of East Java. Surabaya: The East Java Provincial Parliament., 2013.

[3] DPR RI, Constitution of Repubik Indonesia Number 24 on 2007 about Disaster Management. 2007.

[4] BNPB, Regulation of The Head of a National Disaster Response Number 4 on 2008 Regarding the Guidelines of Plan Disaster Response. Indonesia, 2008.

[5] BNPB, "Data Genesis the Disaster of 2014," Jakarta, 2014.

[6] DPR RI, Regulation of the minister in the land the Number 46 Year 2008 about the guidelines of the organization and administration of the Regional Disaster Relief Agency. Indonesia, 2008.

[7] BNPB, Regulation of The Head of National Disaster Response Regulation Number 3 Year 2008 about The Formation Guidelines of The Body of Disaster Area. Indonesia, 2008.

[8] BNPB, Rules of National Disaster Response Number 3 on 2008 about The Formation Guidelines of the Body of Disaster Area. Indonesia, 2008.

[9] BPS, "Report of The Central Statistics Agency 2013," Jakarta, 2014. 